\title{
Past and present status of poultry parasites in Iceland
}

\author{
KARL SKÍRNISSON AND GUĐNÝ RUT PÁLSDÓTTIR \\ Institute for Experimental Pathology at Keldur, University of Iceland, Keldnavegur 3, IS-112, Reykjavik, Iceland \\ E-mail:karlsk@hi.is,gudnyrut@hi.is
}

\begin{abstract}
For centuries flocks of free-ranging hens, Gallus gallus, have been kept on farms in rural Iceland and egglaying hens are occasionally kept in backyards in urban areas. Studies on poultry parasites started in Iceland in the late 1940s, but have been sporadic since the 1970. Recently, 18 birds from nine flocks were examined for endo- and ectoparasites. An eimerid, a nematode, three mites and four mallophagan species were identified. However, altogether, 22 parasite species have been reported from poultry in Iceland; Cryptosporidium, at least three eimerids, two flagellates, six nematodes, five mallophagans, three acarines, a bed bug, and at least one flea species. Haematozoans, trematodes, cestodes, and acanthocephalans have never been detected. Additional dozens of other species parasitize poultry elsewhere in the world, many of them causing severe diseases that demand use of environmentally harmful compounds. Strict import regulations and active surveillance have to be imposed to prevent the introduction of these parasites into Iceland.
\end{abstract}

Keywords: Peridomestic poultry, endoparasites, ectoparasites, Iceland, indigenous species

\section{YFIRLIT}

Snýkjudýr i hoensnum á Íslandi fyrr og nú.

Hænsnarækt hefur verið stunduð til sveita á Íslandi um alda raðir og á seinni árum hefur hænsnahald í bakgörðum í péttbýli færst í vöxt. Rannsóknir á hænsnasníkjudýrum hófust hér á landi rétt fyrir miðja síðustu öld en frá pví um 1970 hafa óverulegar athuganir verið framkvæmdar par til nýlega að innri og ytri sníkjudýr voru rannsökuð á 18 fuglum úr 9 hænsnahópum. Við rannsóknirnar hér á landi hafa alls 22 sníkjudýrategundir fundist í og á hænum: Cryptosporidium sp., prjár hníslategundir, tvær svipudýrategundir, sex práðormar, fimm naglýs, prjár mítlategundir, veggjalús og að minnsta kosti ein flóartegund. Blóðsníkjudýr, ögður, bandormar og krókhöfðar hafa aftur á móti aldrei fundist. Mikill fjöldi annarra sníkjudýra, margir hinir mestu skaðvaldar, sníkja á hænsnum erlendis og er beim iðulega haldið í skefjum með lyfjagjöf og notkun eiturefna. Til að hindra landnám peirra hér á landi er stöðug pörf á árvekni og virku innflutningseftirliti.

\section{INTRODUCTION}

It is an old tradition to keep free-ranging, scavenging hens (Gallus gallus) on Icelandic farms, usually with a rooster. In the past few decades, houseowners in urban areas have also started keeping a few egg-laying hens in their backyards, usually without a rooster. Usually, birds kept in these non-commercial flocks belong to the so-called Icelandic Chicken
Landrace, a genetically diverse breed that was saved from near extinction in the 1980s. These birds posess a wide range of plumage colours and patterns, the comb types can be different (single, double or even triple), and some birds have feather crests or feathered feet (Pálsdóttir \& Hallsson 2016). Archaeological evidence and historical information on chickens in Iceland 
is scarce. Until recent years, however, the Icelandic Chicken Landrace was often believed to be a special old breed that had been isolated in Iceland since the settlement period more than 1100 years ago. At present this is not considered to be correct: recent studies suggest that the present non-commercial poultry population in Iceland is descended from different breeds imported from Europe into Iceland in recent decades and centuries, birds that then mixed with the old landrace population (Pálsdóttir \& Hallsson 2016).

The first commercial poultry farm in Iceland was established at Reykir in Mosfellsbær in 1946. Since then many commercial poultry production units have operated in the country. In 2018 around 250,000 egg-laying hens that more-or-less provide for the domestic egg consumption in Iceland were kept on a total of 15 poultry farms (commercial units with more than 100 laying hens) in Iceland (Hagstofa Íslands 2018). The number of farms and households in Iceland keeping less than 100 hens each have been estimated to be 300-400.

Pioneer work on poultry diseases and parasites started in Iceland a few years before the establishment of the Institute for Experimental Pathology (IEP) at Keldur, Reykjavík, in 1948. This work was later continued by the same experts, whilst at Keldur. Thus, Vigfússon \& Gíslason (1946) dealt with avian tuberculosis (mycobacteriosis), Pálsson (1949a) examined Newcastle disease, and Sigurðsson \& Pálsson (1949) investigated the widespread pullorum disease. The parasite fauna were also examined; Vigfússon \& Gíslason (1947) published an article on coccidiosis, and Pálsson (1949b) and Vigfússon (1968, 1971 \& 1972) dealt with flagellates, helminths, and ectoparasites. Since 1972, however, no systematic studies have been performed on poultry parasites in Iceland. Some sporadic examinations have included identification of Eimeria species causing coccidiosis on a commercial poultry farm (Skirnisson, unpublished data). Also, specimens of helminths and ectoparasites sent to the Laboratory of Parasitology at IEP Keldur have been identified. Recently, dozens of mallophagans collected in the late 1980s and early 1990s from scavaging hens on a small farm in Álftanes, SW Iceland, were mounted and identified.

The aims of this article are to present the results of a survey made on parasite infections and infestation in nine peridomestic poultry flocks in Iceland and report which species have previously been identified in the country.

\section{MATERIAL AND METHODS \\ The birds}

In March 2018 a short notice was published in an Icelandic newspaper expressing the interest of parasitologists at IEP Keldur to obtain hens for parasitological examinations; especially old birds that had stopped egg laying or birds found dead (Morgunblaðið 2018). In the following months, 17 landrace hens and one rooster from nine poultry flocks located in different parts of Iceland were obtained. The flocks from which the birds originated were small, and the total bird number per flock varied from four up to approximately 20 birds. Birds in six of the flocks were free-ranging and scavenging on farms, or around domestic households in the countryside, usually in a flock with a rooster. The remaining three flocks were kept in small enclosures by domestic households in the capital area of Reykjavík. These flocks had four or five egglaying hens.

The birds were packed individually into a plastic bag, labeled with the date and whether they had been found dead or had been sacrificed, approximate age in years, and contact information of the owner. All birds were donated for the study and were stored frozen at $-20^{\circ} \mathrm{C}$ until analysis. The owners were contacted and asked if antiparasitic drugs had been administered to the birds.

\section{Gross morphology examinations}

The birds were thawed overnight at room temperature prior to dissection. Each bird was weighed with an accuracy of $10 \mathrm{~g}$. Tarsus and bill lengths were measured to the nearest $1 \mathrm{~mm}$ with a caliper , and wing-length was measured with a ruler to the nearest $1 \mathrm{~mm}$ (Table 1). 

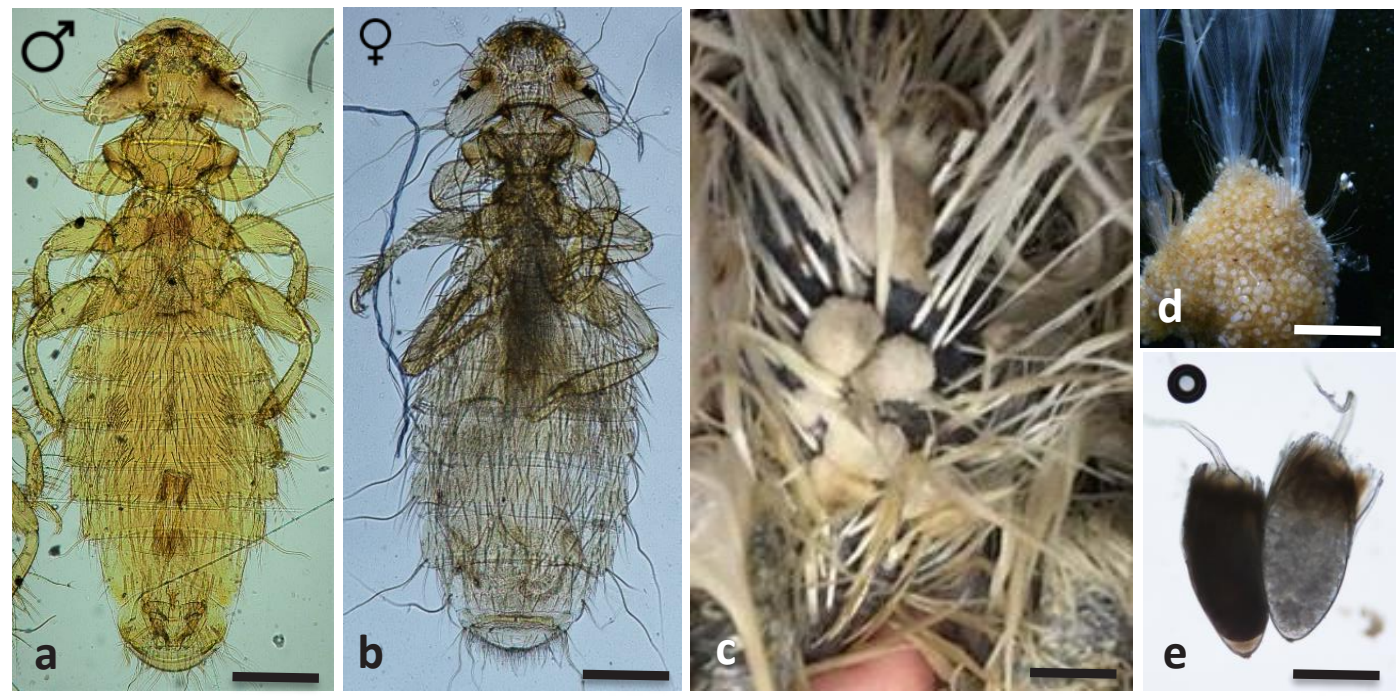

Figure 1. Light microscope photograph of the chicken body louse Menacanthus stramineus (Amblycera: Mallophaga). a. Adult male. b. Adult female. c. Five spherical masses of nits glued to the base of feathers adjacent to the cloaca. d. A single nit mass e. Two nits. Scale bar $\boldsymbol{a}, \boldsymbol{b}: 1 \mathrm{~mm} ; \boldsymbol{c}, \boldsymbol{d}: 0.5 \mathrm{~mm} ; \boldsymbol{e}: 100 \mu \mathrm{m}$.

The macroscopical examination included the examination of the comb shape and colour, plumage density, optical purity, and any damage to flight and tail feathers. Wounds or lesions observed were described and photographed. Bill malformation and the presence of crust or deformation of legs were described and photographed. The presence of pearly nit masses on feather shafts anterior to the vent which are typical for an infestation by Menacanthus stramineus (Figure 1) were searched for and counted.

\section{Collection of ectoparasites}

Ectoparasites were collected with a handheld vacuum cleaner (Princess Turbo Tiger, Type 2755) which was modified for this purpose. The plumage of an intact bird was vacuumcleaned for about two minutes which allowed for systematic and thorough vacuuming of the whole bird. The nozzle $(4.0 \times 1.5 \mathrm{~cm})$ was connected to an external collection chamber fitted with a circular sack-like filter $\left(92 \mathrm{~cm}^{2}\right.$, diameter of pores $2-30 \mu \mathrm{m})$. Its contents were transferred to a $400 \mathrm{ml}$ glass jar using the beam of a water-filled wash bottle. Seven drops of the surfactant TritonH X-100 were added to the liquid to promote particle settling, after which the jar was stored overnight in a refrigerator. Parasites were collected under a dissecting microscope and embedded on slides in Hoyer's medium (Anderson 1954) for later identification and quantification. For further details see Skírnisson et al. (2012) and Skirnisson \& Nielsen (2019).

\section{Dissection, sampling and examination}

The birds were cut open and the inner organs examined macroscopically. Lesions observed as coloured spots, and thickenings or small nodules were excised and fixed in 10\% (v/v) neutral buffered formalin. Tissue samples were formalin treated from the livers of 10 birds (Gg2, Gg8-15, Gg17. Table 1), pancreas of Gg7, proventriculus of Gg15, small intestine of Gg2, and the heart of two birds, Gg15 and Gg16. Histological sections were prepared with standard methods (Suvarna et al. 2013) and stained with HE and the ZiehlNeelsen method. The latter staining procedure was specifically performed to search for avian tuberculosis. Mycobacteria, the causative agent of avian tuberculosis, stains red on a pale blue 

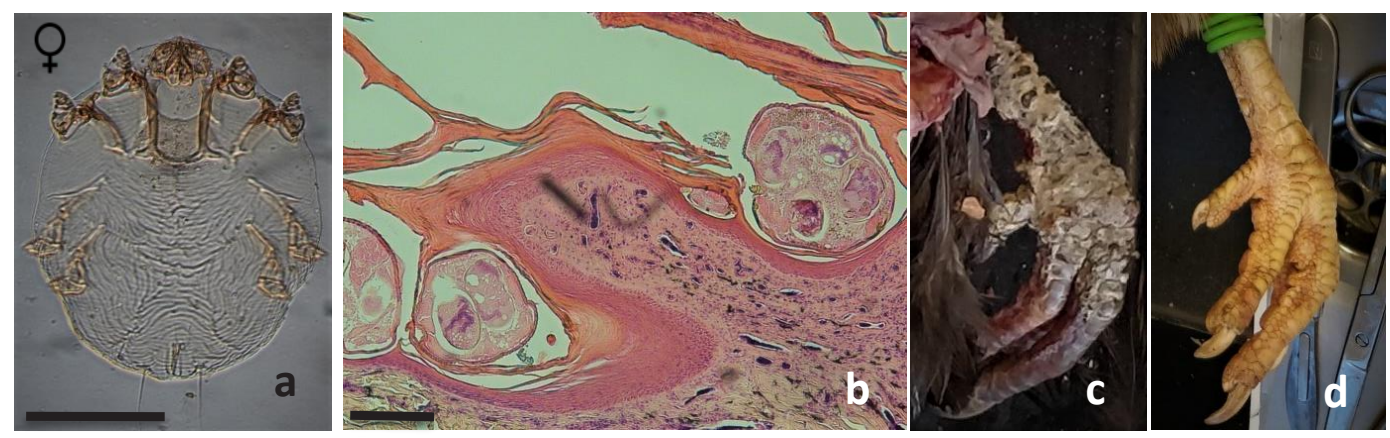

Figure 2. Light microscope photograph of the scaly-leg mite Knemidocoptes mutans and the clinical signs induced when the parasite burrows into the skin underneath the scales of the legs, causing inflammation with exudate and keratinization. a. Adult female. Note the almost spherical shape and short legs. b. Three K. mutans mites seen in a transverse section under the keratine layer, causing hypertrophy of the stratum corneum, Giemsa stain. c. Crusty scales on the leg of an infested hen. d. Leg of an uninfested hen. Scale bar a,b: $250 \mu \mathrm{m}$.

background if present in the tissue sample.

To search for Knemidocoptes mutans, three skin biopsies were taken from the leg and fixed in $10 \%$ neutral buffered formalin, sectioned by standard methods and stained with Giemsa stain (Figure 2) (Suvarna et al. 2013).

The throat and trachea were opened and examined under a dissecting microscope for lesions and the presence of nematodes. The gastrointestinal tract was removed and separated into the following: (a) oesophagus and crop along with trachea and associated connective tissue; (b) glandular stomach and gizzard; (c) duodenum, jejunum and ileum; (d) ceca, separated left and right; and (e) rectum and cloaca. All parts were opened separately with a longitudinal incision and the contents washed into a $100-\mu \mathrm{m}$ mesh. After gently washing with tap water, the contents were transferred to a Petri dish and examined under a stereoscope for worms. Parasites were isolated, counted, and fixed in $70 \%$ ethanol.

A faecal sample from the rectum was collected into $10 \%$ formalin. It was examined by using the formalin-ethyl acetate sedimentation technique (FEAST), a method used to concentrate protozoan cysts, coccidian oocysts, helminth eggs and larvae (Allen \& Ridley 1970, Young et al. 1979). For that purpose, the Faecal Parasite Concentrator (FPC®) kit from Evergreen Scientific was used.
The size and developmental stage of the reproductive organs were described and noted if the bird seemed to be still reproductively active. Parasite identification

Morphological identification of parasites was based on descriptions presented in various articles and textbooks (Soulsby 1965, Calnek 1991, Permin \& Hansen 1998, Rommel et al. 2000, Skoracki 2011, Skoracki et al. 2012).

\section{Photography}

Photographs of parasites were taken with digital cameras attached to a Leica DMLB microscope, equipped for differential interference contrast microscopy (DIC; Nomarski).

\section{RESULTS}

\section{The birds}

The age of the birds varied. Nine hens of the 18 examined birds were six to eight years old; the single rooster examined was believed to be eight years old. The eight remaining hens were either two or four years old (Table 1).

Six of the hens $(35 \%)$ were found dead. Three were abnormally lean, weighing 640, 710 and 800 grams (Table 1). One of them (Gg1) had a broken lower bill that had apparently hindered normal feeding and led to starvation. As detailed below, infestation by amblyceran lice were also believed to have contributed to its death. The other two unusually lean birds 
Table 1. Flock (A-J), bird number, sex, age, body mass, measurments of tarsus and bill and details of parasite infections/infestation of 18 Gallus gallus birds (17 hens, 1 rooster, Gg1-18) from 9 distinct flocks sampled in Iceland in 2018. Intensity of infection (numbers, n) is given for the nematode Heterakis gallinarum (Hg), the prostigmatan mite Syringophilus bipectinatus ( $\mathrm{Sb}$ ), the astigmatan mite Knemidocoptes mutans (Km), the mesostigmatan mite Dermanyssus gallinae (Dg), the amblycerid mallophagans Menacanthus stramineus (Ms) and Menopon gallinae ( $\mathrm{Mg}$ ) and the ischnocerid mallophagans Goniocotes gallinae (Gg) and Liperus caponis (Lc). Infection with Eimeria spp. and Knemidocoptes mutans (Km) (shown with +) were not quantified.

\begin{tabular}{|c|c|c|c|c|c|c|c|c|c|c|c|c|c|c|c|}
\hline Flock & $\begin{array}{l}\text { Bird } \\
\text { Gg \# }\end{array}$ & Sex & $\begin{array}{c}\text { Age } \\
\text { yr }\end{array}$ & $\begin{array}{c}\text { Weight } \\
\text { g } \\
\end{array}$ & $\begin{array}{c}\text { Tarsus } \\
\text { mm }\end{array}$ & $\begin{array}{l}\text { Bill } \\
\mathrm{mm}\end{array}$ & $\begin{array}{c}\text { Eimeria } \mathbf{s p} \\
+/- \\
\end{array}$ & $\begin{array}{c}\mathrm{Hg} \\
\mathrm{n}\end{array}$ & $\begin{array}{c}\text { Sb } \\
\mathbf{n}\end{array}$ & $\begin{array}{c}\mathbf{K m} \\
+/- \\
\end{array}$ & $\begin{array}{c}\text { Dg } \\
\mathrm{n} \\
\end{array}$ & $\begin{array}{c}\text { Ms } \\
\mathbf{n} \\
\end{array}$ & $\begin{array}{c}\text { Mg } \\
\mathbf{n} \\
\end{array}$ & $\begin{array}{c}\text { Gg } \\
\mathbf{n} \\
\end{array}$ & $\begin{array}{c}\text { Lc } \\
\text { n }\end{array}$ \\
\hline \multirow[t]{2}{*}{ A Nes } & 1 & $\mathrm{~F}^{1}$ & 4 & $710^{2}$ & 84 & 23 & - & 19 & - & - & - & $2989^{3}$ & 1495 & 12 & - \\
\hline & 2 & $\mathrm{~F}^{1}$ & 6 & $1380^{2}$ & 92 & 18 & - & 11 & - & + & - & $395^{3}$ & 502 & 15 & - \\
\hline \multirow[t]{2}{*}{ B Hfj } & 3 & $\mathrm{~F}^{1}$ & 7 & $1400^{2}$ & 90 & 17 & - & 3 & - & + & - & - & 285 & 3 & 11 \\
\hline & 4 & $\mathrm{~F}$ & 2 & $1200^{2}$ & 89 & 15 & - & 35 & - & + & - & - & 106 & 12 & 19 \\
\hline \multirow[t]{3}{*}{ C Kol } & 5 & $\mathrm{~F}^{1}$ & 4 & 1300 & 89 & 18 & - & - & - & + & - & 4 & 25 & 4 & - \\
\hline & 6 & $\mathrm{~F}^{1}$ & 4 & 1360 & 91 & 18 & + & 21 & - & + & - & 1 & 31 & 7 & - \\
\hline & 7 & $\mathrm{~F}$ & 4 & 1290 & 93 & 16 & - & 42 & - & + & - & 3 & 25 & 9 & - \\
\hline \multirow[t]{4}{*}{ D Ko2 } & 8 & $\mathrm{~F}$ & 2 & 1830 & 93 & 18 & - & - & - & - & 8 & - & - & - & - \\
\hline & 9 & $\mathrm{~F}$ & 2 & 1850 & 94 & 18 & - & - & - & - & 1 & - & - & - & - \\
\hline & 10 & $\mathrm{~F}^{1}$ & 2 & 1700 & 95 & 19 & - & - & - & - & 7 & - & - & - & - \\
\hline & 11 & $\mathrm{~F}$ & 2 & 2050 & 98 & 18 & - & - & - & - & - & - & - & - & - \\
\hline \multirow[t]{3}{*}{ E Rsk } & 12 & $\mathrm{~F}$ & 6 & 1630 & 93 & 17 & - & 3 & - & - & - & - & 430 & 70 & - \\
\hline & 13 & $\mathrm{~F}$ & 6 & 1080 & 93 & 17 & - & 2 & - & - & - & - & 250 & 40 & - \\
\hline & 14 & $\mathrm{~F}$ & 6 & 1260 & 93 & 17 & - & - & - & - & - & - & 60 & 10 & - \\
\hline F Vol & 15 & $\mathrm{~F}^{1}$ & 8 & 1325 & 88 & 19 & + & 10 & - & + & - & - & 500 & 150 & - \\
\hline G Vid & 16 & $\mathrm{~F}^{1}$ & 7 & $640^{2}$ & 94 & 18 & - & - & - & - & - & $300^{3}$ & 240 & - & - \\
\hline H Enn & 17 & $\mathrm{~F}^{1}$ & 7 & $800^{2}$ & 87 & 18 & - & 13 & 2 & - & - & - & 523 & 62 & - \\
\hline $\mathbf{J}$ Búl & 18 & M & 8 & 2060 & 115 & 24 & - & 157 & - & -4 & - & $220^{3}$ & 1600 & 220 & - \\
\hline
\end{tabular}

${ }^{\text {Inot }}$ egg-laying; ${ }^{2}$ found dead in the flock; ${ }^{3}$ nit masses of Menacanthus stramineus on feathers (see Figure 1c-e); ${ }^{4}$ prominent clinical signs of a Km infestation observed but no mites detected.

were old individuals believed to have died due to their old age. The fourth (Gg2) probably died due to an inguinal hernia. The liver of the fifth (Gg3) was markedly enlarged due to an unknown reason. Also, the cause of death of $\mathrm{Gg} 4$ remains unknown. The remaining 11 hens were sacrificed, most often due to the reason that their egg-laying activity had decreased and they were about to be replaced by younger hens. The only rooster in the survey was sacrificed as it had crippled legs and could no longer walk. Such lesions are caused by the scaly-leg mite $K$. mutans that burrows under the leg scales. The presence of the mite stimulates host epithelial proliferation, resulting in hypertrophy and cornification.
Inspection of the reproductive organs indicated that nine of the 17 hens $(53 \%)$ had completely stopped egg laying. Different sized yolk follicles were still present in the ovaries of the remaining hens, indicating that some of them were able to lay eggs, though probably irregularly.

Histological examinations

The dissection of the birds did not reveal macroscopical tubercles (nodules) or granulomas on the gastrointestinal tract, liver or any other inner organs, all signs that might have indicated an infection of the avian tuberculosis bacteria Mycobacterium avium. Ziehl-Neelsen staining of sections from the liver and single 
nodules fixed from the proventriculus, pancreas small intestine gave negative results.

\section{Drug use}

No antiparasitic drugs had been administered in the flocks examined.

\section{Protozoans}

Three unsporulated Eimeria oocysts of different sizes were found in two hens originating from two distinct flocks (Table 1). Proper identification, which would have required examination of sporulated oocysts from fresh material, was not possible because the birds were frozen prior to analyses. The largest oocyst type measured 24 x $22 \mu \mathrm{m}$, the second form (found in both birds) was $19 \times 17 \mu \mathrm{m}$, and the third and smallest oocyst form measured $15 \times 13 \mu \mathrm{m}$.

\section{Helminths}

No parasites were found in the throat, trachea, oesophagus, crop, glandular stomach, gizzard or under the lining of the gizzard. The nematode Heterakis gallinarum was found in birds from seven of the nine stalls; 2-157 worms were found in $61.1 \%$ of the examined birds (Table 1 , 2). Usually, the nematode was found in the caeca but a few worms (29 of 288, 10\%) were located in the small intestine. Eggs of $H$. gallinarum were detected with the FEAST method in three birds.

Acari

The most common mite observed in the survey was the scaly leg mite $K$. mutans which was present on $44.4 \%$ of the birds and was found in four of the nine flocks (Figure 2, Tables 1, 2). In two flocks all examined hens were infested; in the remaining two flocks one of two hens, and one of three, were infested. The old rooster had severely deformed feet and was unable to walk but no mites were detected in the samples examined from the legs although they had lesions that are typical of infestation.

Two additional mite species were identified (Tables 1,2), i.e. two specimens of Syringophilus bipectinatus (Figure 3) which were found in the filter sample from Gg17 and Dermanyssus

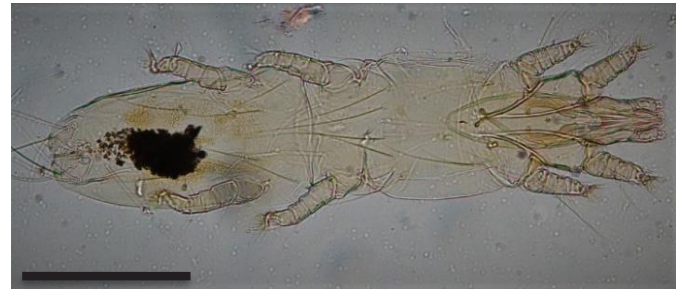

Figure 3. Light microscope photograph of poultry quill mite Syringophilus bipectinatus, adult female (940 $\mu \mathrm{m}-1040)$. Scale bar $250 \mu \mathrm{m}$.

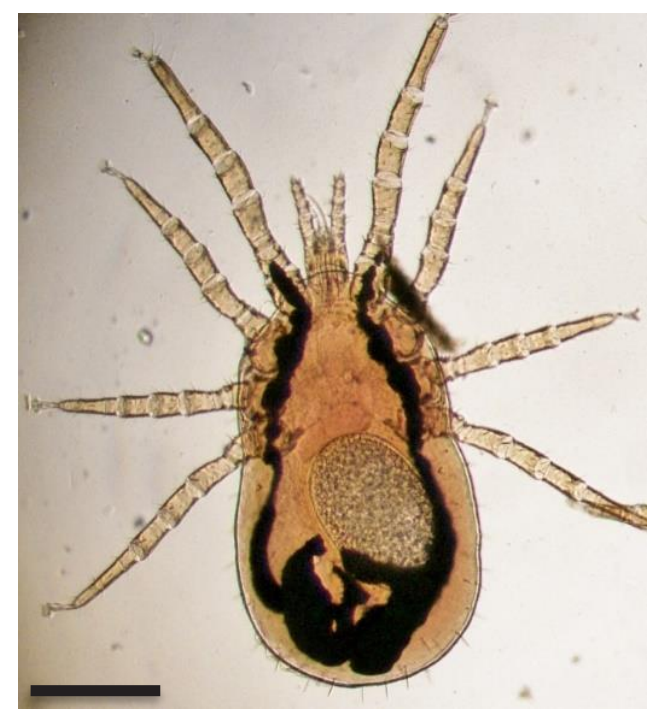

Figure 4. Light microscope photograph of poultry red mite Dermanyssus gallinae, adult female. Scale bar $200 \mu \mathrm{m}$.

gallinae (Figure 4) that was exclusively found in vacuum samples from three of four birds from the domestic flock D.

\section{Mallophaga}

Two amblycerid and two ischnocerid feather lice species were found in the survey (Table 1, 2 ). The most intensive infestation was caused by the feather-shaft louse Menopon gallinae, which was found in all flocks except one, on $77.8 \%$ of the hosts. The other amblycerid, the chicken body louse $M$. stramineus, was detected in four flocks on seven birds (39\%). A large infestation by amblyceran lice, consisting of 
Table 2. Parasite infection/infestation prevalence (\%) and average infection intensity ( \pm SD and range) in 18 Gallus gallus (17 hens, 1 rooster) sampled in 2018 from 9 distinct poultry flocks that lived in different parts of Iceland. Number and percentage (\%) of stalls reported with the respective parasite species are also given.

\begin{tabular}{|c|c|c|c|}
\hline Species & $\begin{array}{c}\text { Infection } \\
\text { prevalence (\%) } \\
\mathrm{n}=18 \\
\end{array}$ & $\begin{array}{l}\text { Average inf. intensity, } \\
\quad \pm \text { SD; (range) }\end{array}$ & $\begin{array}{c}\text { Number of } \\
\text { parasitized stalls } \\
\mathrm{n}=9\end{array}$ \\
\hline \multicolumn{4}{|l|}{ Protozoans } \\
\hline Eimeria spp. & 11.1 & + & $2 / 9$ \\
\hline \multicolumn{4}{|l|}{ Nematoda } \\
\hline Heterakis gallinarum & 61.1 & $29 \pm 42 ;(3-147)$ & $7 / 9$ \\
\hline \multicolumn{4}{|l|}{ Mites } \\
\hline Syringophilus bipectinatus & 5.5 & 2 & $1 / 9$ \\
\hline Knemidocoptes mutans & 44.4 & + & $4 / 9$ \\
\hline Dermanyssus gallinae & 5.5 & $5 \pm 3 ;(1-8)$ & $1 / 9$ \\
\hline \multicolumn{4}{|l|}{ Mallophaga (Amblycera) } \\
\hline Menopon gallinae & 77.8 & $433 \pm 488 ;(25-1600)$ & $8 / 9$ \\
\hline Menacanthus stramineus & 38.8 & $558 \pm 973 ;(1-2989)$ & $4 / 9$ \\
\hline \multicolumn{4}{|l|}{ Mallophaga (Ischnocera) } \\
\hline Goniocotes gallinae & 72.2 & $47 \pm 64 ;(3-220)$ & $7 / 9$ \\
\hline Lipeurus caponis & 11.1 & $15 \pm 4 ;(11-19)$ & $1 / 9$ \\
\hline
\end{tabular}
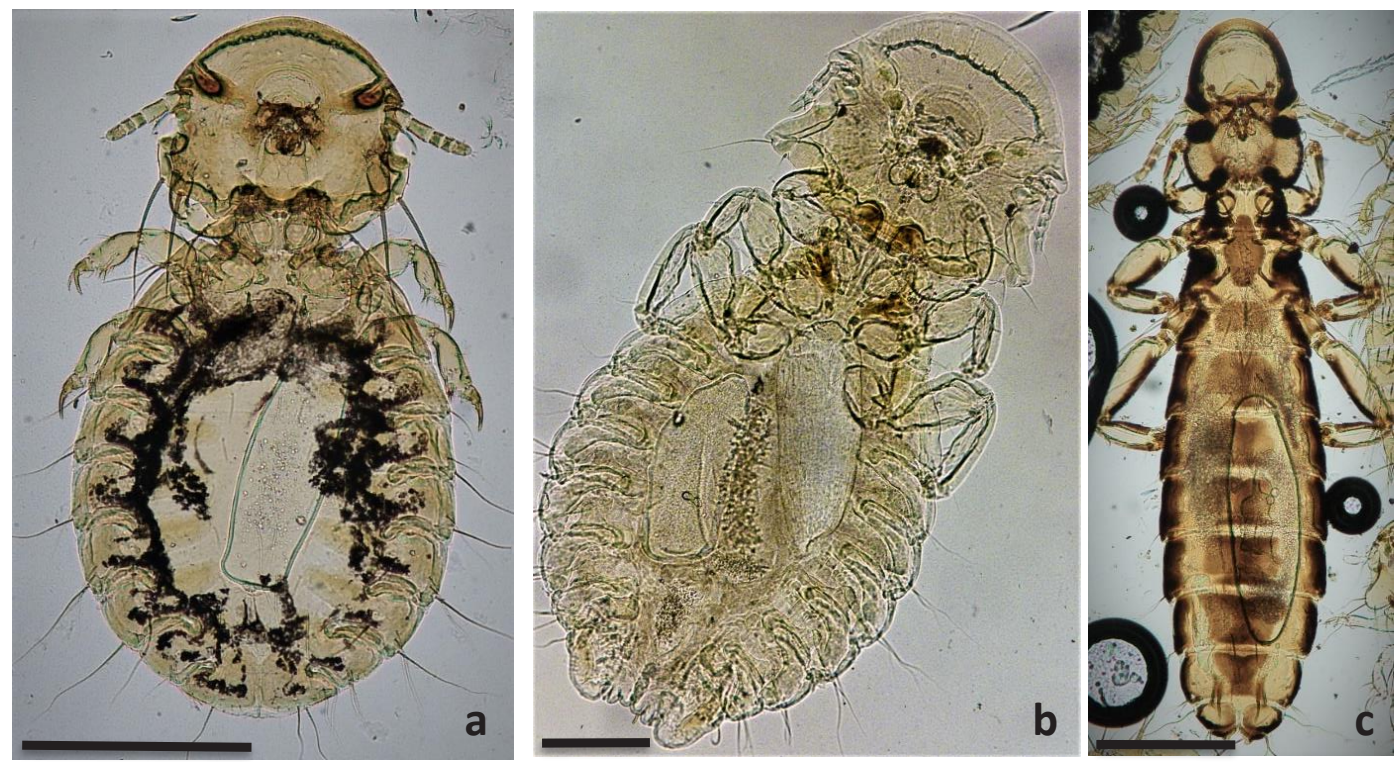

Figure 5. Light microscope photograph of three feather lice (Ischnocera: Mallophaga) found on poultry in Iceland. All are females as seen by the presence of eggs. a. Fluff louse Goniocotes gallinae: b. Brown chicken louse Goniodes dissimilis. c. Wing louse Lipeurus caponis. Scale bar: $0.5 \mathrm{~mm}$. 
4.484 specimens, was detected in the filter sample collected from Gg1.

Nit masses, deposited as white clusters at the base of feathers around the vent, were observed on the four hens that had M. stramineus lice numbers varying from 220 to 2989 individuals per bird. In contrast, no such masses were detected on the feathers of the three lightly infested birds from flock D (Table 1).

The ischnocerid fluff- louse Goniocotes gallinae was found on $72.2 \%$ of the hosts in seven of the nine flocks, whereas the ischnocerid wing louse Lipeurus caponis occurred only on the two birds examined from the backyard flock B (Figure 5, Tables 1, 2).

\section{DISCUSSION}

\section{Parasite species identified}

This survey detected relatively few parasite species, i.e. three different-sized unsporulated eimerids, one nematode, three acarines, and four mallophagans in the 18 birds from nine peridomestic poultry flocks. Some previously identified parasites in Iceland were not found, including five nematode species (Capillaria annulata, $C$. caudinflata, $C$. contorta, $C$. obsignata and Ascaridia galli), the mallophagan Goniodes dissimilis, the flea Ceratophyllus gallinae and the bedbug Cimex lectularius. Already in the 1940s Eimeria tenella and Eimeria necatrix had been reported to cause coccidiosis in poultry (Vigfússon \& Gíslason 1947). Also, the flagellates Trichomonas gallinarum and Histomonas meleagridis were reported (Vigfússon 1972) and in the early 1990s, Cryptosporidium meleagridis was also confirmed (Skirnisson et al. 1993). The three above-mentioned protozoans were not systematically searched for in the present survey.

\section{Poultry parasites not yet identified in Iceland} There are dozens of species that parasitize poultry in Western Europe (Rommel et al. 2000) such as haematozoans, trematodes, cestodes, and acanthocephalans that have never been detected in poultry in Iceland and are regarded to be absent. In some cases the lack of an obligate intermediate host explains the absence. Furthermore, representatives of many other genera, e.g. nematodes belonging to the genera Oxyspirura, Strongyloides, Syngamus, Amidostomum, and Trichostrongylus, have never been reported to parasitize poultry in Iceland although they are known to occasionally parasitize wild birds in the country. Thus, $A$. acutum and $A$. anseris (Skirnisson 2015) are known to occur in anseriform birds and T. tenuis is found in the rock ptarmigan Lagopus muta (Skirnisson et al. 2012) and in domestic and wild geese (Anser anser) (Skírnisson, unpublished). Similarily, acarines that infest poultry in Western Europe such as Argas, Ornithonyssus, Megninia, Dermoglyphus,Columbiphilus and Epidermoptes have never been reported in Iceland. The same applies to the commonly occurring poultry mallophagan Cuclotogaster heterographus and some insects, e.g. Lucilia sericata (Rommel et al. 2000). Thus, only a small portion of potential poultry parasites has been confirmed in Iceland. However, most of them could easily be introduced into the country if strict official precautions are not followed, e.g. via the import of infected or infested birds or contaminated eggs. Traces of faecal matter on the latter can potentially contain parasite eggs, protozoan cysts or oocysts.

\section{Importance of active surveillance}

Recently, a considerable infestation $(12,200$ mites, 12,000 eggs) of the northern fowl mite Ornithonyssus sylviarum was detected on a single Gouldian finch Erythrura gouldiae that died after having been brought from the Netherlands to a quarantine station in Iceland. This mite is the commonest and most important permanent parasite of poultry in all major production areas of the USA and is also recognized as a serious pest throughout the temperate zone of other countries (Calnek 1991). In this case, to prevent the possible establishment of this severe pathogen in Iceland, all the cage birds imported together with the infested finch were destroyed and the quarantine facility was disinfected. Thus, a potential infection source was eradicated. 


\section{Protozoans}

In the 1940s, the eimerid species E. tenella and $E$. necatrix were reported as severe pathogens in chicken flocks in Iceland. On occasion, up to $30-50 \%$ of flocks died and those birds that survived the infection recovered slowly, were weak and did not develop normally (Vigfússon \& Gíslason 1947). In recent decades these host-specific pathogens have sometimes been identified at the IEP Keldur in connection with coccidiosis on commercial poultry farms. Oocysts of E. tenella and E. necatrix are considerably larger (average size $22.0 \mathrm{x}$ 19.0 and $22.4 \times 17.2 \mu \mathrm{m}$, respectively) than the smallest oocyst $(15 \times 13 \mu \mathrm{m})$ detected in the present study, having the same average size $(15.6 \times 13.4)$ as reported for E. mivati (Rommel et al. 2000). However, to confirm the occurrence of E. mivati in Iceland sporulated oocysts have to be examined. Nevertheless, at least two known and one uncertain eimerid species occur in Icelandic poultry. It is feasible to consider that most common poultry eimerids should be present in Iceland. This has, for example, been shown to be the case in sheep in Iceland that have been confirmed to host the world fauna of sheep eimerids (Skirnisson 2007).

Vigfússon (1972) reported the presence of the flagellates $T$. gallinae and $H$. meleagridis in Icelandic poultry. At present, however, only inadequate information is available on their occurrence. In the study described here, no clinical signs were noticed in the throat or oesophagus of the birds which would have been indicative of $T$. gallinae infection. Richter (1983b) reported the parasite from domestic pigeons in Iceland.

In the early 1990s Cryptosporidium meleagridis oocysts were searched for in 29 chickens from seven poultry flocks. The parasite was found in six birds in three flocks (Skírnisson et al. 1993).

\section{Nematoda}

Almost half a century ago Vigfússon (1971) reported the nematode $H$. gallinarum as a very common parasite of peridomestic poultry in Iceland. In the present survey, the worm was confirmed in seven out of the nine flocks examined. Thus, no marked changes seem to have occurred. However, the other commonly found nematode, A. galli (Vigfússon 1971), was not detected in the present study. In recent decades $A$. galli has twice been found inside eggs of free-ranging hens after the movement of the nematode up to the oviduct. Thus, it is still regarded as occurring in Icelandic peridomestic poultry.

No representatives of the genus Capillaria were found in the present survey. Vigfússon (1971) mentioned four species in peridomestic poultry, C. annulata, C. caudinflata, C. contorta and $C$. obsignata, but it is not clear if these species were identified by the author himself from Icelandic material. Our identifications of specimens collected in the early 1990s from hens from the farm in Alftanes confirmed the presence of both C. obsignata and C. caudinflata. Moreover, C. obsignata was identified from peridomestic poultry on a farm in Eyjafjörður, North Iceland, and a heavy infection by this species was identified in 2012 in a domestic pigeon Columba livia from the larger Reykjavík area. C. caudinflata is a common parasite of rock ptarmigan (Skirnisson et al. 2012).

Neither $C$. annulata nor $C$. contorta have been identified at Keldur in recent decades in poultry samples. However, C. contorta is commonly found in the throat of the gyrfalcon (Falco rusticolus) in Iceland, causing so-called frounce (yellow cheesy plaques in throat, crop, and oesophagus) that sometimes can be fatal, especially in young falcons. It is unknown if $T$. gallinae also contributed to these clinical signs in some of the cases (Christensen et al. 2015).

\section{Acarina}

The quill mite $S$. bipectinatus lives inside the quills of poultry. It was detected for the first time in Iceland in the present study. There is contrasting information in the literature regarding its effect on the host. Calnek et al. (1991) believed that the mite might cause partial or complete loss of feathers, Gritschenko (1973) believed, however, that the feeding of $S$. 
bipectinatus produced an itching which caused chickens to pick at infested feathers. On the other hand, recent data indicate that quill mites do not induce pathological changes in wild birds, even during heavy infestations (Skoracki 2011). The detection of S. bipectinatus in one of the nine examined flocks in this study indicates that its occurrence is rare in Iceland. Discovering it at all was probably due to the well-known efficiency of the vacuum-cleaning method used in the survey (Skirnisson and Nielsen 2018).

The scaly leg mite $K$. mutans was first identified in Iceland from an old rooster with distorted and crippled legs brought to Keldur in 2014. In the present study, this mite had an extensive distribution, confirmed in four poultry flocks (of nine) from different parts of the country. Actually, the only rooster examined came from the fifth flock. It had severely crippled legs that strongly suggested a previous infestation with the scaly leg mite although not detected in the unusually thick, typical section prepared from its leg.

The red poultry mite $D$. gallinae was first reported to infest poultry in Iceland in 1879 (Snorri Jónsson 1879). Since then, it has repeatedly been identified, not only from poultry but also from other birds (domestic pigeon C. livia) and mammalian hosts (house cats Felis catus) (reviewed by Skirnisson 2017). Furthermore, the mite has been reported from pigeon stalls (Richter 1983a). In the present study, the red poultry mite was detected in a single flock (D). The flock originally consisted of five newly hatched chickens that were purchased from a commercial poultry farm and transferred to a small, fenced-in backyard stall which consisted of an insulated wooden house that was perfectly designed to fulfil the environmental requirements of a few egglaying domestic hens. The small house was heated up with an infrared heat bulb. Egg laying was excellent for approximately a year and a half. Then it started to decline and when 20 months old one hen died in the house. A few days later a high density of the red-poultry mite was confirmed in the small house. For example, thousands of mites had been attracted to an electrical clock that was used to control the illumination period of the infrared heating bulb. Some months later the remaining four hens in the flock were sacrificed and examined. Vacuuming of their plumage revealed the presence of only a few mites, and one of them actually appeared to be free of infestation. This finding was not unexpected. D. gallinae is known to hide in cracks and crevices in stalls and it primarily visits the birds at night for blood meals. These findings underline that the search for the red poultry mite should be performed in the stalls rather than on the birds themselves. As this was not done in the present study our results are likely to be an underestimate of prevalence.

Regarding the origin of the infestation in flock $\mathrm{D}$, the red poultry mite most probably accompanied the newly-hatched chickens to their future home and the mite has repeatedly been confirmed on the farm where the chickens were purchased. No other parasites were detected in the flock.

\section{Mallophaga}

Overgaard (1942) reported the amblycerid feather lice Menopon pallidum (syn. gallinae) and $M$. stramineus from poultry in Iceland, and Pálsson (1949b) listed various methods to control poultry lice. A study of dozens of mallophagans sampled from hens in Álftanes in the late 1980s and early 1990s revealed five species: M. gallinae, M. stramineus, $G$. gallinae, L. caponis and the brown chicken louse Goniodes dissimilis. In the present study $G$. dissimilis was not detected.

An interesting mallophagan infestation pattern was noticed. Without exception, all individuals in a flock had identical mallophagan infestations. If a given mallophagan species occurred on one hen in a flock, it also occurred on the other hens in the flock. Furthermore, the intensity of infection seemed to be linked to the living conditions, treatment, and welfare of the birds. Thus, the light intensities of the three mallophagans on apparently healthy hens from flock $\mathrm{C}$ are considered to reflect their effective preening abilities and successful control of their infestations. In contrast, the opposite, i.e. 
huge amblyceran infestations, were observed on undernourished and diseased hens from flock A (Table 1).

The eggs of $M$. stramineus were mostly deposited in white clusters at the base of feathers, especially around the vents (Figure $1 \mathrm{c}-\mathrm{e})$. Such clusters were noticed in all the hens except on the lightly infested birds from flock C. Thus, developed infestations should be easily recognized with the naked eye.

A total of 4,485 mallophagans were sampled from the most intensively infested hen ( $\mathrm{Gg} 1$, flock A). This hen died with a broken lower bill which presumably hindered normal feeding as well as preening ability which is the method that healthy hens with an undamaged bill use to control mallophagan infestations by removing lice (and insects) from the plumage. The life cycle of poultry lice is short. Nits hatch in about four to five days, the nymph stage takes 9-12 days and adult mallophagans survive for approximately 12 days. Each day they lay on average one or two eggs so that if hens are unable to remove the lice a huge infestation can develop in some weeks or months (Rommel et al. 2000).

\section{CONCLUSIONS}

During the past 75 years 22 parasite species have been reported from poultry in Iceland; Cryptosporidium, at least three eimerids, two flagellates, six nematodes, five mallophagans, three acarines, a bed bug, and at least one flea. Haematozoans, trematodes, cestodes or acanthocephalans have never been found to infect poultry in Iceland. This list represents only a small part of known poultry parasites. Dozens of other species, many of them severe pathogens, parasitize poultry elsewhere in the world, where some of them cause severe diseases that demand the use of various, often environmentally harmful, drugs. Strict import regulations and active surveillance have to be maintained to prevent their establishment in Iceland.

So far, the research on poultry parasites in Iceland has been sporadic. The present status of some of the species, e.g. the flagellates, is questionable or unknown. Further research, e.g. utilizing available tools of molecular biology, should be performed to clarify and improve our knowledge of the present status and perhaps the discovery of previously undescribed species in Iceland. A specific survey is needed to identify the eimerid fauna of peridomestic poultry in Iceland that are usually not protected against the most pathogenic coccidians as performed in the commercialized intensive systems.

In Iceland pathogenic parasites, such as $D$. gallinae, $K$. mutans, and the amblycerid mallophagans, have been shown to be able to markedly influence the health of poultry and even contribute to mortalities. Therefore, after consulting a veterinarian, antiparasitic treatment of severely affected individuals should be considered.

\section{ACKNOWLEDGEMENTS}

Sincere thanks are devoted to the poultry owners that donated their birds for the study. Also, to Sigurður H. Richter and Matthías Eydal who collected some of the material dealt with in the article, and Birkir bór Bragason, who proofread the manuscript.

\section{REFERENCES}

Allen AV \& Ridley DS 1970. Further observations on the formol-ether concentration technique for faecal parasites. Journal of Clinical Pathology $23,545-546$.

Anderson LM 1954. Hoyer's solution as a rapid permanent mounting medium for bryophytes. Bryologist 57, 242-244.

Calnek BW 1991. Diseases of Poultry. 9th edition. Wolfe Publishing Ldt. Iowa State University Press.

Christensen ND, Skírnisson $K$ \& Nielsen OK 2015. The parasite fauna of the gyrfalcon (Falco rusticolus) in Iceland. Journal of the Wildlife Diseases 51, 929-933.

Gritschenko EF 1973. The biology and ecology of the quill mite Syringophylus bipectinatus Heller, 1880. Proceedings $3^{\text {rd }}$ International Conference of Acarology. D. Milan \& M. Rosicki (Eds.). Czechoslovak Academy of Science, Prague, 515516. 
Hagstofa Íslands 2018. https://hagstofa.is/talnaefni/ atvinnuvegir/landbunadur/bufe-og-uppskera/ Visited 22.10.2019.

Morgunblaðið 2018. https://www.mbl.is/frettir/ innlent/2018/03/02/oska_eftir_lifsleidum haenum/ Visited 22.10.2019.

Overgaard C 1942. Mallophaga and Anoplura. The Zoology of Iceland. Vol 3, Part 42. 22 pp.

Permin A \& Hansen JW 1998. Epidemiology, diagnosis and control of poultry parasites. FAO Animal Health Manual. Food and Agriculture Organisation of the United Nations. Rome. 159 pp.

Pálsdóttir AH \& Hallsson JH 2016. Landnámshcenan - Er góð saga gögnum betri?Hugvísindaping. https://prezi.com/-nfszqnxwhz9/landnamshnan-ergo-saga-gognum-betri/ Visited 4.1.2020.

Pálsson PA 1949a. [Newcastle-disease in poultry]. Alifuglarcektin 1, 1-2. [In Icelandic].

Pálsson PA 1949b. [Poultry louse and its eradication]. Alifuglarcektin 1, 1-3. [In Icelandic].

Richter SH 1983a. [Infectious diseases of pigeons]. Dýraverndarinn 69(1), 3-7. [In Icelandic].

Richter SH 1983b. [More about infectious diseases of pigeons]. Dýraverndarinn 69(3), 23. [In Icelandic].

Rommel M, Eckert J, Kutzer E, Körtling W \& Schnieder T 2000. Veterinärmedicinische Parasitologie. Parey, Berlin. 915 pp.

Sigurðsson B \& Pálsson PA 1949. [Pullorum disease]. Alifuglarcektin 1, 1-5. [In Icelandic].

Skirnisson K 2007. Eimeria spp. (Coccidia, Protozoa) infections in a flock of sheep in Iceland: Species composition and seasonal abundance. Icelandic Agricultural Sciences 20, 73-80.

Skirnisson K 2015. Association of helminth infections and food consumption in common eiders Somarteria mollissima in Iceland. Journal of Sea Research 104, 41-50.

Skirnisson K 2017. What is known about the poultry red mite in Iceland? Vísindavefurinn, 3. maí 2017. http://visindavefur.is/svar.php?id=73932http:// visindavefur.is/svar.php?id=73932 [In Icelandic]. Visited 22.10.2019.

Skírnisson K, Eydal M \& Richter SH 1993. [Cryptosporidium spp. in animals in Iceland]. Dýralceknaritið 1993, 4-13. [In Icelandic with English summary].
Skírnisson K \& Nielsen OK 2019. Quill mite infestation of rock ptarmigan Lagopus muta (Aves: Phasianidae) in relation to year and host age, sex, body condition and density. Parasitology Research 118, 2643-2650.

Skirnisson K, Thorarinsdottir ST \& Nielsen OK 2012. The parasite fauna of rock ptarmigan (Lagopus muta) in Iceland: Prevalence, intensity, and distribution within the host population. Comparative Parasitology 79, 44-55.

Skoracki M 2011. Quill mites (Acari: Syringophilidae) of the Palaearctic region. Zootaxa 2840, 1-414.

Skoracki M, Zabludovskaya SA \& Bochkov AV 2012. A review of Prostigmata (Acariformes: Trombidiformes) permanently associated with birds. Acarina 20, 67-107.

Snorri Jónsson 1879. [New scab mite]. Norðanfari 18, 36-37.

Soulsby EJL 1965. Textbook of Veterinary Clinical Parasitology, Vol. 1. Helminths. Oxford, Blackwell Scientific Publications. 1120 pp.

Suvarna SK, Layton C \& Bancroft JD 2013. Bancroft's Theory and Practice of Histological Techniques. Churchill Livingstone, Elsevier. 7th Edition.

Vigfússon H \& Gíslason G 1946. [Avian tuberculosis]. Freyr 41, 223-227. [In Icelandic].

Vigfússon H \& Gíslason G 1947. [Coccidiosis]. Freyr 42, 109-112. [In Icelandic].

Vigfússon H 1968. [Poultry diseases]. Handbók bcenda 18, 1-12. [In Icelandic].

Vigfússon H 1971. [Helminths of poultry]. Freyr 67, 458-459. [In Icelandic].

Vigfússon H 1972. [Black-head disease]. Freyr 68, 21-22. [In Icelandic].

Young KH, Bullock SL, Melvin D \& Spruill CL 1979. Ethyl acetate as a substitute for diethyl ether in the formalin-ether sedimentation technique. Journal of Clinical Microbiology 10, 852-853.

Manuscript received 20.11.2019 Accepted 24.1.2020 